Arab World English Journal (AWEJ) $2^{\text {nd }}$ Special Issue on Covid 19 Challenges January 2022 DOI: https://dx.doi.org/10.24093/awej/covid2.13

\title{
A Systematic Review of Online Learning during COVID 19: Students' Motivation, Task Engagement and Acceptance
}

\author{
Mujahid Mohtar \\ Faculty of Education, \\ Universiti Kebangsaan Malaysia, Selangor, Malaysia \\ Corresponding Author: mujahid.my19@gmail.com \\ Melor Md Yunus \\ Faculty of Education \\ Universiti Kebangsaan Malaysia, Selangor, Malaysia
}

Received: 8/4/2021 Accepted:12/28/2021 Published: 1/24/2022

\begin{abstract}
The COVID 19 pandemic has forced the education sector to switch to online learning. To make the transition a success, there is a need to understand students' perception towards online learning and design a learning experience around it. Thus, the aim of this paper is to identify students' perceptions towards online learning in terms of motivation, task engagement and acceptance. The systematic literature review method was used to search for relevant papers and synthesize the findings. 40 articles from the year 2020 obtained from Google Scholar. It is found that the most used method in studying students' perception is the quantitative method and students' acceptance was the most discussed topic. It is also found that the primary factors influencing motivation and acceptance are sense of ownership and accessibility respectively. In terms of task engagement, only half of the findings reveal that students are engaged in online learning. In summary, the three main constructs are important items that should be taken into consideration when teaching an online course to ensure the success of the course. Through this systematic review, future research can identify and explore different areas and perspectives on this topic.
\end{abstract}

Keywords: acceptance, COVID-19, motivation, online learning, systematic review, task engagement

Cite as: Mohtar, M., \& Md Yunus, M. (2022). A Systematic Review of Online Learning during COVID 19: Students' Motivation, Task Engagement and Acceptance. Arab World English Journal (AWEJ) $2^{\text {nd }}$ Special Issue on Covid 19 Challenges (2) 202-215.

DOI: https://dx.doi.org/10.24093/awej/covid2.13 


\section{Introduction}

The COVID 19 pandemic took the world by storm in 2019. This virus spread to countries all around the world at an unprecedented speed. Due to its contagious nature and the length of time it took for symptoms to manifest, governments around the world have initiated lockdowns in order to curb the spread. A number of sectors were halted because of the lockdown. One of them being the education sector. Students in schools and universities were prevented from going to their respective campuses for almost a year now. Numerous institutions had chosen to postpone all in-person classes, including laboratories and other learning experiences and move all of the courses online (Hodges, Moore, Lockee, Trust, \& Bond, 2020). Students and teachers alike were forced to stay at home. They had to rely on online learning as a substitution for face to face learning. The sudden transition was a difficult yet necessary process in times of pandemic (Ranellucci \& Bergey, 2020).

In order to manage the transition well, Ali (2020) noted that infrastructure support, staff readiness, and student acceptability are among the factors that must be considered. During the pandemic, the move from offline to online learning happens quickly. Researchers are publishing papers left and right about the strategies and techniques that they use to teach online. As such, there is a need to learn more about students' attitudes regarding online learning and how it is utilized in the learning and teaching process. This will aid in the implementation of a successful online learning experience. Failure to consider the students' perspective on online learning will result in a poor learning experience. Besides that, understanding the students' perspective will allow decision makers to analyze and fulfil the needs of students in the online learning context. There are numerous studies that have been done to determine students' perception on online learning during COVID 19. However, there is a lack of systematic review studies on the students' perception on online learning. Thus, the aim of the aim of this paper is to identify students' perceptions towards online learning in terms of motivation, task engagement and acceptance. The systematic literature review method was utilized.

In delving deeper into students' perspective, this research will narrow down the perspective into three main constructs namely motivation, task engagement and acceptance. These three items will guide the search for previous literature and categorize the findings accordingly. All of the previous literature that elaborated on these constructs will be included and synthesized. The result of the synthesis will give a clear overview of what is actually happening with the students as they are going through the online learning experience. In this study, three research objectives were outlined which are:

1) Identify the factors that motivate students to learn in an online class

2) Identify the level of task engagement during an online class

3) Identify the factors which influence students' acceptance of online learning.

\section{Literature review}

\section{COVID 19 pandemic and education}

COVID 19 was an unprecedented event that took the world by storm. Almost all countries around the globe were affected at the same time. In the education sector, all institutions were halted due the lockdown order imposed by governments (Daniel, 2020). When traditional classes could no longer be held, educators turned to online learning. Before the pandemic, educators use education technology which includes e-learning and m-learning sparingly. However, due to the 
pandemic, it offers expanded opportunities for learning versatility during the lockdown (Rahiem, 2020) education technology looked like the saviour of the education sector during the pandemic (Teras, Teras, Arinto, Brunton, Daryono \& Subramaniam, 2020). As the need for a more robust online learning experience, large-scale, national efforts were poured into remote learning, distance education and online learning (Ali, 2020). That being said, teachers and students alike are still at the crossroad between fully embracing online learning and clinging on to traditional face to face class. Online learning was initially thought of as a temporary solution (Torrau, 2020). Hodges et al. (2020) noted that the online learning experience that is being implemented now is not the true form of online learning, it is called Emergency Remote Learning. Despite all of the praise for online learning's numerous advantages, it is still viewed as a supplementary and complimentary teaching and learning tool, with the teacher or instructor remaining at the centre of the process (Kaur \& Bhatt, 2020).

\section{The transition from face to face learning to online learning}

Most governments have demanded that face-to-face classes be discontinued immediately, pushing students and teachers to transition to online teaching and virtual education almost immediately (Daniel, 2020). Online learning has always had a stigma of being inferior to traditional face to face class. The sudden unprepared transition would have negatively impacted the perception towards online learning. This difficult transition would ultimately seal online learning as the less robust experience (Hodges et al., 2020). Some institutions have already used education technology even before the pandemic. Subsequently, the transition was very smooth and easily acceptable by teachers and students alike. On the flip side, there are also some institutions that struggled to accommodate with the rapid switch to online learning (Ali, 2020). The experience of learning from home can be suitable for some students while challenging for others. The experience will be influenced by differing individual needs and social interactions (Teras et al., 2020). The main issue with this sudden transition is that institutions focus on bringing pedagogy such as content, methods, strategies, and assessment from the traditional class into an online platform. There was no thought on changing the pedagogy to better suit the online learning needs of the students (Crawford, et al., 2020). As a result, the online learning experience felt forced and ineffective. This has affected students' perception on online learning.

\section{Definitions for the three constructs}

In this study, three main constructs were identified which are motivation, task engagement and acceptance. These constructs will become the guidance for the direction of this study. As such, a clear definition is needed in order to outline what those constructs refer to. Firstly, motivation refers to "energy, direction, persistence and equifinality - all aspects of activation and intention." (Ryan \& Deci, 2000, p. 69). This definition is in line with Self-Determination Theory (SDT). In this theory, every individual has 3 basic psychological needs that must be met in order for him to develop himself (Ryan, Ryan, Di Domenico \& Deci, 2019). These 3 basic needs are autonomy, competence and relatedness. These 3 items will influence the level of motivation a person will have when carrying out a particular task. Autonomy refers to the level of initiative and ownership of a particular task. This means that a person is able to begin and take control of the task on his own without having to be forced by external parties. Next, competence refers to the sense of mastery of a particular skill. This means that the level of motivation depends on the presence of "optimal challenges, positive feedback and the opportunity for growth" (Ryan \& Deci, 2020, p. 2). Lastly, relatedness refers to the sense of belongingness to a particular 
community. The amount of respect and care the community have to one another will affect the level of motivation of the individual.

Moving on, the second construct, which is task engagement, refers to students' ability to participate in a particular task given by the teacher or lecturer. This definition is derived mainly from a systematic review on Students Engagement done by Bedenlier, Bond, Buntins, ZawackiRichter \& Kerres (2020). In that systematic review, the author states that student engagement is described as the amount of energy and effort students put into their learning community, as measured by a variety of behavioural, cognitive, and affective indicators in a period of time. (Bond, Buntins, Bedenlier, Zawachi-Richter, \& Kerres, 2020). On the other hand, task here refers to any form of activity or work the lecturer gives to the students whether it is required to be done immediately during class or as a homework to be done outside of the class. In the construct of engagement, there also exist the opposite side which is disengagement. Previous research has noted that simply using technology without proper planning and pedagogy will cause disengagement among the students (Bond et al., 2020). This means that if the online task given is not carefully planned and executed, it will impede the learning process (Howard, Ma \& Yang, 2016).

Lastly, the third construct is acceptance. Acceptance, in this study, will use the original Technology Acceptance Model as its framework. Davis (1989) put forth this model as an extension of a theory called Theory of Reasoned Action (as cited in Sangrà Vlachopoulos, \& Cabrera, 2012). This model aims to "determine the acceptance of the use of computers and pertinent technologies in various technologies and user groups" (Salloum \& Shaalan, 2018, p. 27). Technology Acceptance Model has seen many changes and modifications, but the core model remains the same. According to the original concept, external variables influence two personal beliefs: perceived usefulness and perceived ease of use (Davis, 1989). These two beliefs will determine whether technology will be used or not in a particular situation. Davis (1989) defined perceived usefulness as the "degree to which a person believes that using a particular system would enhance his or her work" while the definition of perceived ease of use is "the degree to which a person believes that using a particular system would be free from effort." (as cited in Sangrà et al., 2021, p. 27) These definitions will be the guiding principles to which the literature in this systematic review would be included or not.

Although there have been numerous studies that have highlighted the issues and experiences of online learning from the students' perspective, there is a lack of a systematic literature review on this topic. A systematic literature review would help to summarize and synthesize previous studies for the purpose of highlighting the general consensus for their findings. Doing so will enable researchers to obtain the gist of the overarching studies and choose different routes in carrying out future research.

\section{Method}

This study applies the systematic analysis method on available literature on Google Scholar. The search process was done from October 2020 to November 2020. The purpose of this systematic literature review is to provide an overview of what is happening in the education field during the course of the COVID 19 pandemic. This review focuses only on the students' perspective and experience in this unstable learning environment. A better understanding of the students' 
perspective will surely shed some light into executing better learning practices. Hence, in this study, the five-phase method proposed by Khan, Kunz, Kleijnen, \& Antes (2003) was used. This method has been used to produce original research as well as help researchers to critically analyze, evaluate and synthesize complex ideas (Khan et al., 2003). The five phases of the systematic literature review are:

1) Framing questions for a review

2) Identifying relevant work

3) Assessing the quality of study

4) Summarizing the evidence

5) Interpreting the findings

\section{Phase 1: Framing questions for a review}

The COVID 19 pandemic has left a huge impact on education. All of the educational institutions had to make the leap into online learning regardless whether they were ready or not. In ensuring the quality of education is not deterred, a deep understanding about the students' online learning experience has to be made. Hence, this study aims to analyze students' motivation, task engagement and acceptance of online learning during the pandemic. The papers that would be analyzed would be between 2019 to 2020 . The research questions are:

1) what motivates students to learn using technology during the pandemic?

2) what is the level of task engagement among students when using online learning?

3) what are the factors that influence the students' acceptance of learning using online means?

\section{Phase 2: Identifying relevant work}

The systematic review's second phase is to identify relevant work. This phase consists of two processes. The first step is to gather all relevant publications that relate to the study's research questions. The second step was to identify appropriate articles based on the criteria for inclusion and exclusion. This study only collects data from journal articles. The only database used was Google Scholar. In addition, the articles must be published between 2016 to 2020. Articles from before the pandemic emerged were chosen as well because they too hold valuable information about the online learning experience and practices which can help both teachers and students during this pandemic. In the searches in Google Scholar, variations of the keyword "online learning," "technology in education," "COVID 19" and "motivation, task engagement and acceptance," were used.

\section{Phase 3: Assessing the quality of study}

In ensuring the quality of this study, the journal articles found in Google Scholar would be selected based on the framework criteria. The inclusion and exclusion criteria were identified. The selection of the articles would be done using the inclusion and exclusion criteria. This would ensure the relevance of the articles as well as maintaining the focus of this study. Table 1 shows the inclusion criteria and Table 2 shows the exclusion criteria: 
Arab World English Journal (AWEJ) 2nd Special Issue on Covid 19 Challenges January 2022

Table 1: Inclusion criteria

\begin{tabular}{|c|l|}
\hline i. & Online learning must be implemented \\
\hline ii. & Sample or respondents are from various levels of education \\
\hline iii. & The studies evaluate students' online learning experience \\
\hline iv. & Teaching and learning using online means \\
\hline v. & Published between 2019 and 2020 \\
\hline
\end{tabular}

Table 2: Exclusion criteria

\begin{tabular}{|c|l|}
\hline i. & Online learning is not implemented \\
\hline ii. & The studies did not evaluate students' online learning experience \\
\hline iii. & Teaching and learning which did not use online learning \\
\hline iv. & Articles were not published between 2019 and 2020 \\
\hline v. & Other than journal articles \\
\hline
\end{tabular}

Both inclusion and exclusion criteria have been laid out in order to ensure the direction of this study is clear. 5 inclusion criteria were identified which include online learning must be implemented, sample or respondents are from various levels of education, the studies evaluate students' online learning experience, studies must be related to teaching and learning using online means and published between 2019 and 2020. These criteria will be used to find relevant articles to answer the research questions. On the other hand, 5 exclusion criteria were identified which are online learning is not implemented, the studies did not evaluate students' online learning experience, teaching and learning which did not use online learning, articles were not published between 2019 and 2020 and academic papers that are not journal articles. These criteria will be used to filter out irrelevant articles to ensure that this review is focused and not muddled with unnecessary information.

\section{Phase 4: Summarizing the evidence}

The database used in this study is Google Scholar. In the search bar, the keywords "online learning," "COVID 19," and "student's perspective" were used. The results revealed 231 links. The results were then filtered according to its accessibility, type of research paper and the inclusion and exclusion criteria. 50 papers were not included as they were inaccessible. 110 papers found in the search were not related to the scope of the study. After going through the papers in inclusion and exclusion criteria, 31 papers were removed. In summary, from the 231 results, only 40 articles were included in this study.

\section{Phase 5: Interpreting the findings}

The final phase is the interpretation of the findings using content analysis to analyze the data. Content analysis can be accomplished by using quantitative, qualitative and mixed methods so that categorical data can be used to identify trends. From the search in Google Scholar, 231 results appeared on students' perspective on online learning during COVID 19 pandemic. Only 40 were selected that fitted the inclusion criteria. Table 3 shows the number of articles sorted 
Arab World English Journal (AWEJ) 2nd Special Issue on Covid 19 Challenges January 2022

according to the methodology used. From the table, quantitative method was used the most, followed by qualitative method and mixed method.

Table 3: Numbers of studies based on methods

\begin{tabular}{|l|l|}
\hline Method & Numbers of studies \\
\hline Quantitative & $19(47.5 \%)$ \\
\hline Qualitative & $13(32.5 \%)$ \\
\hline Mixed method & $8(20 \%)$ \\
\hline
\end{tabular}

\section{Findings}

After going through the five phases of the Systematic Literature Review, the findings yield a total of 40 relevant papers. The categories of those papers are further broken down into the three constructs of this study namely motivation, task engagement and acceptance. Table 4 shows the percentage of studies according to their respective constructs.

Table 4: Number of studies based on constructs

\begin{tabular}{|l|l|}
\hline Construct & Numbers of studies \\
\hline Motivation & $6(15 \%)$ \\
\hline Task Engagement & $11(27.5 \%)$ \\
\hline Acceptance & $23(57.5 \%)$ \\
\hline
\end{tabular}

\section{Discussion}

The aim of this systematic review is to synthesize the findings of previous studies related to the students' perspectives on online learning. The researcher zooms in on the topic by narrowing it down to three main constructs namely motivation, task engagement and acceptance. As such, there are 3 objectives of this review namely:

1) Identify the factors that motivate students to learn in an online class

2) Identify the level of task engagement during an online class

3) Identify the factors that influence students' acceptance of learning using online means

40 articles have been analyzed in this study. Among those three constructs, studies about Acceptance yielded the most results (23 articles; 57.5\%), followed by Task Engagement (11 articles; $27.5 \%$ ) and Motivation (6 articles; $15 \%$ ).

In terms of motivation, previous studies have shown that When implementing online learning courses during the COVID 19 pandemic, there are a lot of elements that can encourage students. One of them being the sense of ownership (Oe, Takemoto \& Ridwan, 2020; Oh, Chan \& Kim, 2020). Asynchronous approaches such as gamification-based modules and e-portfolios can enhance the level of motivation among students as they can develop a sense of ownership towards the task given. Students are able to take control of the learning process. They are able to do research on their own about the subjects that they are learning (Oe et al, 2020). Besides that, 
content relevance is also a factor in motivating the students (Famularsih, 2020; Qunfei, 2020). Students find it motivating when their teacher provided materials that are relevant to what they are learning. In addition, students also find it motivating when they can explore content which are of personal interest and relevance (Qunfei, 2020). Moreover, online learning can encourage active participation among students (Susilawati, 2020). All of this is in line with the notion of autonomy found in psychological needs in Self Determination Theory which explains about the level of ownership of a task is related to the level of motivation of students (Ryan \& Deci, 2000; Ryan \& Deci, 2020).

Moving on to the level of task engagement, the trend of the previous studies follows the outline from the literature review where there exist both situation of engagement and disengagement. 6 out of $11(55 \%)$ articles revealed findings of engagement and 5 out of 11 (45\%) articles revealed findings of disengagement. The pieces of evidence of high level of task engagement include indicators such as positive perception of the students towards online classes (Schlenz, Schmidt, Wostmann, Kramer, \& Schulz-Weidner, 2020; Hattar et al., 2020; Bestari, Faiza, \& Mayekti, 2020), high satisfaction with the course (Khalil et al., 2020) and high scores in online tests (Mulenga \& Marban, 2020). Students also find the task engaging when a novel learning experience is introduced such as the case of using mixed reality modules (Sepasgozar, 2020). This is in line with the study by Ali (2020) who stated that there is a huge investment poured into remote learning by governments worldwide. As such, the novelty of online learning can be experienced by many students. That being said, there is also the other half of the studies which show that students have a low level of engagement with the online tasks during this pandemic. Many of the students point out the ineffectiveness of online tasks by comparing it to face-to-face classes (Besser, Flett, \& Zeigler-Hill, 2020; Almoayad, Almuwais, Alqabbani, \& Benajiba, 2020). Students struggle to transition from a face-to-face to an online approach. The amount of responsibilities towards their own independent learning is a huge burden. Aside from that, students also reported that they find it difficult to follow video conferencing class due to distractions learning at home (Chen et al., 2020) as well as the inability to interact with tactile learning materials (Srinivasan, 2020). This may be attributed to the students' initial perception of online learning as the less robust version of education (Hodges et al., 2020). There are also students who are simply not excited about technology-enhanced learning (Wang \& East, 2020). These findings are consistent with the previous literature in which unplanned pedagogy will lead to disengagement (Bond et al., 2020; Howard et al., 2016). The sudden transition from a normal class into an online class is a challenging process. If there was no effort in transforming the pedagogy to better suit the online class, the students will not find the class to be effective (Crawford, 2020).

Furthermore, in terms of acceptance, there are a number of factors that push students to accept and use technology to learn during the COVID 19 pandemic. These factors include accessibility, flexibility, interactivity and familiarity. Firstly, students accept the use of online distance learning due to its accessibility. The online platforms themselves were easy to use (Sobaih et al., 2020). This means is that students are able to attend online classes during the lockdown (Khan et al., 2020; Sahbaz, 2020). Students also reported that they could access the learning materials easier (Shukla, 2020; Hasan \& Khan, 2020; Sahbaz, 2020; Chola, 2020). Next, the second factor is flexibility. Flexibility refers to the ability for students to access the learning experience anytime (Elhadary et al., 2020; Al-Noafie, 2020; Shukla, 2020; Hasan \& Khan, 2020) 
and anywhere (Shukla, 2020). This level of flexibility is attributed to asynchronous learning approach where teachers and lecturers have uploaded the learning materials online for the students to go through. By using this approach, Elhadary at al. (2020) states that students are able to rewatch lecture videos which contributes to the increased level of understanding among students. Moreover, in the use of synchronous learning approach such as virtual classes, students find the experience to be very interactive. Students state that the ability to interact with teachers and their peers is a huge advantage of virtual classes (Wangmo et al., 2020; Alahmadi \& Alraddadi, 2020; Lin \& Gao, 2020). Sharif et al. (2020) states that "students may find it rewarding to ask a question, offer a comment and receive instant feedback" (p. 372). Furthermore, there are also studies that show that students can accept the online learning experience due to them being familiar with the technology beforehand (Alharbi \& Meccawy, 2020; Guo, 2020). Students have positive attitudes towards the online learning experience as they have been using a variety of mobile applications already (Alharbi \& Meccawy, 2020).

With that being said, there are also factors that impede students' acceptance of online distance learning during the pandemic. These include technical difficulties and lack of infrastructure (Hebebci at al., 2020). Aside from that, students complained about the structure of online learning or lack thereof (Nambiar, 2020). Some students find online learning to be ineffective because it was their first time carrying it out (Cuschieri \& Agius, 2020) while others say that certain subjects and classes, such as lab work and tutorials, are not suitable to be carried out online (Chola, 2020; Gillis \& Krull, 2020). Finally, disturbances in the flow of classes can impede students' willingness to accept online distance learning (Nambiar, 2020). Jett (2020) pointed out that there are more distractions when students are learning online at home. All in all, these factors are tied together to the previous literature of Technology Acceptance Model (Davis, 1989). These external elements, according to the model, play a role in affecting the two perceptions of perceived usefulness and perceived ease of use of technology. As such, educators need to take in all of these factors into consideration when implementing online classes so as to make sure that the students are able to accept the learning experience. This will ultimately lead to the success of online classes. In addition to that, Chen et al. (2020) found that students' personal factor plays a secondary role in user satisfaction. Platform availability plays a more important role. This is supported by Almulhem (2020) who stated that students' satisfaction is tied to three main factors, namely course content quality, system quality and service quality; none of which are related to personal factor.

\section{Conclusion}

This study aims to identify the students' perceptions on online learning in terms of motivation, acceptance and task engagement. To do that, the systematic literature review method was utilized. 40 papers were selected and synthesized. In terms of motivation, the primary factor that influenced it is sense of ownership. Acceptance, on the other hand, was primarily influenced by accessibility. Finally, the level of task engagement of students towards online learning is at a moderate level. These three constructs are influenced by many other factors and should be approached holistically. In summary, educators are recommended to design learning experience that focuses on independent learning and student-centred learning. Doing so will allow students to take control of their own learning experience, become motivated to learn, engaged with the lesson and accept the potential of online learning. That being said, this will inevitably lead to different issues; however, it will ensure that students learn responsibly and can improve at their 
Arab World English Journal (AWEJ) 2nd Special Issue on Covid 19 Challenges January 2022

own pace. Future research should explore on the effectiveness and implementation of independent learning.

\section{About the Authors}

Mujahid Mohtar is a Teaching English as a Second Language (TESL) undergraduate student at the Faculty of Education, Universiti Kebangsaan Malaysia (UKM). ORCid ID:

https://orcid.org/0000-0003-0000-4346

Dr. Melor Md Yunus is an Associate Professor at the Faculty of Education, Universiti Kebangsaan Malaysia and is currently the Deputy Dean (Research and Innovation) at the Faculty of Education, Universiti Kebangsaan Malaysia (UKM). She holds a B.A. in English (Linguistics) from the University of Nevada-Reno, USA and an M.A. in TESL from the Arizona State University, USA. She then earned her Ph.D. in Education (TESL) from the University of Bristol, UK. Her areas of concentration are TESL, language pedagogy and the use of technology in TESL. Her expertise is in the area of Technology-enhanced Language Learning (TELL). ORCid ID : https://orcid.org/0000-0001-7504-7143

\section{References}

Abd Rahman, S. F., Yunus, M. M., \& Hashim, H. (2019). A Technology Acceptance Model (TAM)L Malaysian ESL Lecturers' Attitude in Adapting Flipped Learning. Jurnal Pendidikan Malaysia 44(1), 43-54. DOI: http://dx.doi.org/10.17576/JPEN-2019-44.01SI04

Adnan, M., \& Anwar, K. (2020). Online learning amid the COVID-19 pandemic: Students' perspectives . Journal of Pedagogical Sociology and Psychology 2(1), 45-51. http://www.doi.org/10.33902/JPSP. 2020261309

Alahmadi, N. S., \& Alraddadi, B. M. (2020). The Impact of Virtual Classes on Second Language Interaction in the Saudi EFL Context: A Case Study of Saudi Undergraduate Students . Arab World English Journal (AWEJ) 11(3), 56-72. https://dx.doi.org/10.24093/awej/vol11no3.4

Alharbi, A. S., \& Meccawy, Z. (2020). Introducing Socrative as a Tool for Formative Assessment in Saudi EFL Classrooms. Arab World English Journal (AWEJ) 11(3), 372384. https://dx.doi.org/10.24093/awej/vol11no3.23

Ali, W. (2020). Online and Remote Learning in Higher Education Institutes: A Necessity in light of COVID-19 Pandemic. Higher Education Studies 10(3), 16-25. DOI: 10.5539/hes.v10n3p16

Allam, S. N., Hassan, M. S., Mohideen, R. S., Ramlan, A. F., \& Kamal, R. M. (2020). Online Distance Learning Readiness During Covid-19 Outbreak Among Undergraduate Students. International Journal of Academic Research in Business \& Social Sciences, 642-657.

Almoayad, F., Almuwais, A., Alqabbani, S. F., \& Benajiba, N. (2020). Health Professional Students' Perceptions and Experiences of Remote Learning During the COVID-19 Pandemic. International Journal of Learning, Teaching and Educational Research, 19(8), 313-329. https://doi.org/10.26803/ijlter.19.8.17

Almulhem, A. (2020). Investigating the effects of quality factors and organizational factors on university students' satisfaction on e-learning system quality. Cogent Education, 1-16. https://doi.org/10.1080/2331186X.2020.1787004 
Arab World English Journal (AWEJ) 2nd Special Issue on Covid 19 Challenges January 2022

Al-Nofaie, H. (2020). Saudi University Students' Perceptions towards Virtual Education During Covid-19 Pandemic: A Case Study of Language Learning via Blackboard. Arab World English Journal (AWEJ) 11(3), 4-20. https://dx.doi.org/10.24093/awej/vol11no3.1

Bai, X., Ola, A., Reese, S., Eyob, E., \& Bazemore, S. (2020). A Study Of The Effectiveness Of Remote Instruction From Students' Perspectives. Issues in Information Systems, 21(4), 143-155.

Bedenlier, S., Bond, M., Buntins, K., Zawacki-Richter, O., \& Kerres, M. (2020). Facilitating student engagement through educational technolgy in higher education: A systematic review in the field of arts and humanities. Australasian Journal of Educational Technology, 126-150.

Besser, A., Flett, G. L., \& Zeigler-Hill, V. (2020). Adaptability to a Sudden Transition to Online Learning During the COVID-19 Pandemic: Understanding the Challenges for Students. Scholarship of Teaching and Learning in Psychology, 1-21. http://dx.doi.org/10.1037/st10000198

Bestari, A. C., Faiza, D., \& Mayekti, M. H. (2020). Instagram Caption As Online Learning Media On The Subject Of Extended Writing During Pandemic Of Covid 19. Surakarta English And Literature Journal, 3(1), 9-21.

Bond, M., Buntins, K., Bedenlier, S., Zawachi-Richter, O., \& Kerres, M. (2020). Mapping research in student engagement and educational technology in higher education: a systematic evidence map. International Journal of Educational Technology in Higher Education, 1-30. https://doi.org/10.1186/s41239-019-0176-8

Carter Jr, R. A., Rice, M., Jackson, Yang, S., \& Jackson, H. A. (2020). Self-regulated learning in online learning environments: strategies for remote learning. Information and Learning Science, 121(5/6), 321-329. DOI 10.1108/ILS-04-2020-0114

Chen, T., Peng, L., Yin, X., Rong, J., Yang, J., \& Cong, G. (2020). Analysis of User Satisfaction with Online Education Platforms in China during the COVID-19 Pandemic. Healthcare, 1-26. doi:10.3390/healthcare 8030200

Chen, Z., Cao, H., Deng, Y., Gao, X., Piao, J., Xu, F., Zhang, Y. \& Li, Y. (2020). A Large-Scale Mixed-Methods Analysis of Live Streaming Based Remote Education Experience in Chinese Colleges during the COVID-19 Pandemic. 1-23.

Chola, R., Kasimba, P., George, R., \& Rajan, R. (2020). COVID-19 and E-learning: Perception of Freshmen Level Physics Students at Lusaka Apex Medical University. International Journal of Academic Research and Development, 5(4), 67-76.

Crawford, J., Butler-Henderson, K., Rudolp, J., Malkawi, B., Glowatz, M., Burton, R., Magni, P. A. \& Lam, S. (2020). COVID-19: 20 countries' higher education intra-period digital pedagogy responses. Journal of Applied Learning \& Teaching, 3(1), 9-28.

Cuschieri, S., \& Agius, J. C. (2020). Spotlight on the Shift to Remote Anatomical Teaching During Covid-19 Pandemic: Perspectives and Experiences from the University of Malta. Anatomical Sciences Education, 1-9.

Daniel, J. (2020). Education and the COVID-19 Pandemic. Prospect 49, 91-96. https://doi.org/10.1007/s11125-020-09464-3

Elhadary, T., Elhaty, I. A., Mohamed, A. A., \& Alawna, M. (2020). Evaluation of Academic Performance of Science and Social Science students in Turkish Universities during COVID-19 Crisis. Journal of Critical Reviews, 7(11), 1740-1751. 
Arab World English Journal (AWEJ) 2nd Special Issue on Covid 19 Challenges January 2022

Famularsih, S. (2020). Students' Experiences in Using Online Learning Applications Due to COVID-19 in English Classroom. Studies in Learning and Teaching, 1(2), 112-121. https://doi.org/10.46627/silet

Gillis, A., \& Krull, L. M. (2020). COVID-19 Remote Learning Transition in Spring 2020: Class Structures, Student Perception, and Inequality in College Courses. Teaching Sociology, 48(4), 283-299. DOI: 10.1177/0092055X20954263

Guo, J., Huang, F., Lou, Y., \& Chen, S. (2020). Students' perceptions of using mobile technologies in informal English learning during the COVID-19 epidemic: A study in Chinese rural secondary schools. Journal of Pedagogical Research , 1-9. http://dx.doi.org/10.33902/JPR.2020063786

Hasan, N., \& Khan, N. H. (2020). Online Teaching-Learning During Covid-19 Pandemic: Students' Perspective. The Online Journal of Distance Education and e-Learning, 8(4), 202-213.

Hattar, S., AlHadidi, A., Sawair, F. A., Abd Alraheam, I., El-Ma'aita, A., \& Wahab, F. K. (2020). Impact of COVID-19 pandemic on dental academia. Students' experience in online education and expectations for a predictable practice. Research Square, 1-16. https://doi.org/10.21203/rs.3.rs-54480/v1

Hebebci, M. T., Bertiz, Y., \& Alan, S. (2020). Investigation of Views of Students and Teachers on Distance Education Practices during the Coronavirus (COVID-19) Pandemic. International Journal of Technology in Education and Science, 4(4), 267-282.

Hodges, C., Moore, S., Lockee, B., Trust, T., \& Bond, A. (2020, March 27). The Difference Between Emergency Remote Teaching and Online Learning. From educause.edu: https://er.educause.edu/articles/2020/3/the-difference-between-emergency-remoteteaching-and-online-learning

Howard, S. K., Ma, J., \& Yang, J. (2016). Student Rules: Exploring patterns of students' computer-efficacy and engagement with digital technologies in learning. Computers \& Education, 29-42.

Jett, C. C. (2020). The Qualms and Quarrels with Online Undergraduate Mathematics: The Experiences of African American Male STEM Majors. Investigations in Mathematics Learning, 1-11. https://doi.org/10.1080/19477503.2020.1827663

Kaur, N. \& Bhatt, M. S. (2020). The Face of Education and the Faceless Teacher Post COVID19. Journal of Humanities and Social Sciences Research 2(S), 39-48. https://doi.org/10.37534/bp.jhssr.2020.v2.nS.id1030.p39

Kerr, D., Ratcliff, J., Tabb, L., \& Walter, R. (2019). Undergraduate nursing student perceptions of directed self-guidance in a learning laboratory: An educational strategy to enhance confidence and workplace readiness. Nurse Education in Practice 42, 1-6. https://doi.org/10.1016/j.nepr.2019.102669

Khalil, R., Mansour, A. E., Fadda, W. A., Almisnid, K., Aldamegh, M., Al-Nafeesah, A., Alkhalifah, A. \& Al-Wutayd, O. (2020). The sudden transition to synchronized online learning during the COVID-19 pandemic in Saudi Arabia: a qualitative study exploring medical students' persepctives. BMC Medical Education, 1-10. https://doi.org/10.1186/s12909-020-02208-z

Khan, K. S., Kunz, R., Kleijnen, J., \& Antes, G. (2003). Five Steps to Conducting a Systematic Review. Journal of the Royal Society of Medicine , 118-121. 
Arab World English Journal (AWEJ) 2nd Special Issue on Covid 19 Challenges January 2022

Khan, M. Y., \& Tufail, H. (2020). An Investigation into the Effectiveness of MALL during COVID-19 at the Higher Education in Pakistani EFL Classrooms. Global Language Review, $V(I), 175-185$. doi:10.31703/glr.2020(V-I).19

Lin, X., \& Gao, L. (2020). Students' sense of community and perspectives of taking synchronous and asynchronous online courses. Asian Journal of Distance Education, 15(1), 169-179. https://doi.org/10.5281/zenodo.3881614

Mulenga, E. M., \& Marban, J. M. (2020). Is COVID-19 the Gateway for Digital Learning in Mathematics Education? Contemporary Educational Technology, 1-11. https://doi.org/10.30935/cedtech/7949

Mulenga, E. M., \& Marban, J. M. (2020). Prospective Teachers' Online Learning Mathematics Activities in The Age of COVID-19: A Cluster Analysis Approach. EURASIA Journal of Mathematics, Science and Technology Education, 16(9), 1-9. https://doi.org/10.29333/ejmste/8345

Nambiar, D. (2020). The impact of online learning during COVID-19: students' and teachers' perspective. The International Journal of Indian Psychology, 8(2), 783-793. DOI: $10.25215 / 0802.094$

Oe, H., Takemoto, T., \& Ridwan, M. (2020). Is Gamification a Magic Tool?: Illusion, Remedy, and Future Opportunities in Enhancing Learning Outcomes during and beyond the COVID-19. Budapest International Research and Critics in Linguistics and Education (BirLE) Journal, 3(3), 1401-1414. https://doi.org/10.33258/birle.v3i3.1198

Oh, J.-E., Chan, Y. K., \& Kim, K. V. (2020). Social Media and E-Portfolios: Impacting Design Students' Motivation Through Project-Based Learning. IAFOR Journal of Education: Undergraduate Education, 8(3), 41-58. DOI: 10.22492/ije.8.3.03

Qunfei, X., Abdullah, N., \& Mustapha, S. M. (2020). The Influencing Factors And Incentive Measures Of College Students' Online English Learning Motivation. Journal of Education and Social Sciences 15(2), 74-81.

Rahiem, M. D. H. (2020). The Emergency Remote Learning Experience of University Students in Indonesia amidst the COVID-19 Crisis. International Journal of Learning, Teaching and Educational Research, 19(6), 1-26. https://doi.org/10.26803/ijlter.19.6.1

Ranellucci, J., \& Bergey, B. W. (2020). Using Motivation Design Principles to Teach Screencasting in Online Teacher Education Courses. Jl. of Technology and Teacher Education, 28(2), 393-401.

Ryan, R. M., \& Deci, E. L. (2000). Self-Determination Theory and the Facilitation of Intrinsic Motivation, Social Development and Well-Being. American Psychologist, 68-78. DOI: 10.1037110003-066X.55.1.68

Ryan, R. M., \& Deci, E. L. (2020). Intrinsic and Extrinsic Motivation from a Self-Determination Theory Perspective: Definitions, theory, practices and future directions. Contemporary Educational Pyschology. https://doi.org/10.1016/j.cedpsych.2020.101860

Ryan, R. M., Ryan, W. S., Di Domenico, S. I., \& Deci, E. L. (2019). The Nature and the Conditions of Human Anatomy and Flourishing: Self-determination theory and basic psychological needs. The Oxford handbook of human motivation, 89-110.

Sahbaz, A. (2020). Views and Evaluations of University Students about Distance Education During the COVID-19 Pandemic. Educational Process International Journal 9(3), 185198. DOI: 10.22521/edupij.2020.93.5 
Arab World English Journal (AWEJ) 2nd Special Issue on Covid 19 Challenges January 2022

Salloum, S. A., \& Shaalan, K. (2018). Investigating students' acceptance of e-Learning system in Higher Educational Environments in the UAE: Applying the Extended Technology Acceptance Model (TAM).

Sangrà, A., Vlachopoulos, D., \& Cabrera, N. (2012). Building an inclusive definition of elearning: An approach to the conceptual framework. The International Review of Research in Open and Distributed Learning, 13(2), 145-159.

Schlenz, M. A., Schmidt, A., Wostmann, B., Kramer, N., \& Schulz-Weidner, N. (2020). Students' and lecturers' perspective on the implementation of online learning in dental education due to SARS-CoV-2 (COVID-19): a cross-sectional study. BMC Medical Education, 1-7. https://doi.org/10.1186/s12909-020-02266-3

Sepasgozar, S. M. (2020). Digital Twin andWeb-Based Virtual Gaming Technologies for Online Education: A Case of Construction Management and Engineering. Applied Sciences, 132. doi:10.3390/app10134678

Sharif, M., Rahim, S., Tahir, A., Minallah, S., Sheikh, M. W., \& Riaz, M. U. (2020). Perception of Dental Students Regarding Online Classes during the Pandemic. Pak Armed Forces Med J, 369-374.

Shukla, V. D. (2020). Impact of online teaching learning process of chemistry during COVID19: A case study of Government City College in Hyderabad, Telangana. Journal of Xi'an University of Architecture \& Technology, 2075-2084.

Sobaih, A. E., Hasanein, A. M., \& Abu Elnasr, A. E. (2020). Responses to COVID-19 in Higher Education: Social Media Usage for Sustaining Formal Academic Communication in Developing Countries. Sustainability 12, 1-18. doi:10.3390/su12166520

Susilawati, S., \& Supriyatno, T. (2020). Online Learning Through WhatsApp Group in Improving Learning Motivation in the Era and Post Pandemic COVID-19. Jurnal Pendidikan: Teori, Penelitian dan Pengembangan, 5(6), 852-859.

Teras, M., Teras, H., Arinto, P., Brunton, J., Daryono, D., \& Subramaniam, T. (2020). COVID19 and the push to online learning: reflections from 5 countries . Digital Culture and Education.

Torrau, S. (2020). Exploring teaching and learning about the Corona crisis in social studies webinars A case study. Journal of Social Science Education 19, 15-29. DOI 10.4119/jsse3456

Tümen Akyıldız, S. (2020). College Students' Views on the Pandemic Distance Education: A Focus Group Discussion. International Journal of Technology in Education and Science, 4(4), 322-334.

Wang, D., \& East, M. (2020). Constructing an Emergency Chinese Curriculum during the Pandemic: A New Zealand Experience. International Journal of Chinese Language Teaching, 1(1), 1-19. https://doi.org/10.46451/ijclt.2020.06.01

Wangmo, U., Nesor, M. R., Choki, S., Om, L., Dorji, K., Dema, N., . . . Tshering, N. (2020). Students' Perception on E-Learning in Punakha Dzongkhag in Bhutan. Asian Journal of Education and Social Studies, 11(2), 18-24. DOI: 10.9734/AJESS/2020/v11i230286

Zakaria, M. I., Mastima, M. S., \& Khalid, F. (2019). A Systematic Review of M-Learning in Formal Education. International Journal of Innovation, Creativity and Change, 1-24. 